\title{
Valproic Acid-Induced Priapism in a Child
}

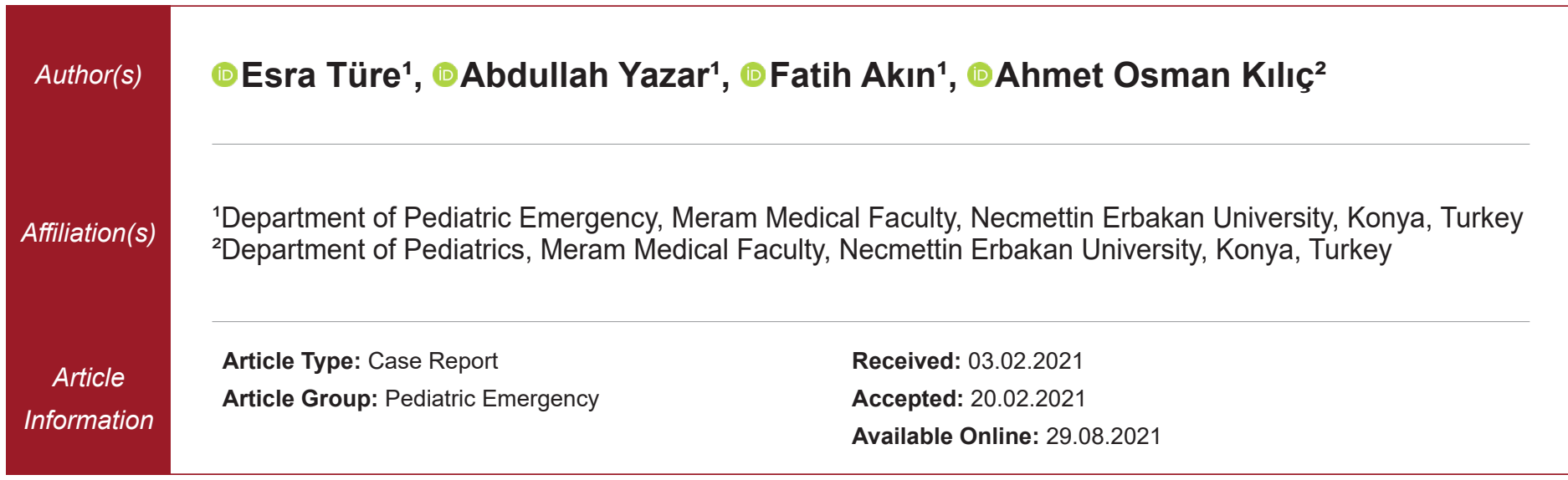

Cite this article as: Türe E, Yazar A, Akın F, Kılıç AO. Valproic Acid-Induced Priapism in a Child. J Pediatr Acad 2021; 2: 74-76.

\section{Abstract}

A complete or partial involuntary erection that occurs in absence of a sexual stimulation and lasts longer than four hours is defined as priapism. Etiology usually includes sickle cell disease or hematologic malignancies. Less common causes include trauma, spinal cord injury, medications, congenital syphilis, parotitis, Fabry's disease and retroperitoneal sarcoma. Priapism is a urologic emergency that varies by ischemic and non-ischemic episodes. Ischemic injury to cavernous tissues leads to erectile dysfunction. Early recognition of priapism, determination of the type and the treatment are crucial in preventing potential long-term complications caused by priapism. With this case of priapism caused by a treatment with valproic acid, it was aimed to point out priapism which is a urologic emergency.

Keywords: Priapism, valproic acid, children, pediatric emergency, urologic emergency

\section{Introduction}

A complete or partial involuntary erection that occurs in absence of a sexual stimulation and lasts longer than four hours is defined as priapism. Etiology usually includes sickle cell disease or hematologic malignancies. Less common causes include trauma, spinal cord injury, medications, congenital syphilis, parotitis, Fabry's disease and retroperitoneal sarcoma. ${ }^{1}$ Treatment of this urological emergency aims prevention of erectile dysfunction and psychological sequelae. ${ }^{2}$ There is still no widely accepted algorithm for management of priapism in children. Most cases of priapism improve with treatment of the underlying disease. However, refractory cases are managed conservatively by corporeal irrigation. Some cases require a corporeal cavernous-spongious shunt. ${ }^{1}$

With this case of priapism caused by a treatment with valproic acid, it was aimed to point out priapism which is a urologic emergency. 


\section{Case}

An eight year-old male patient admitted to our pediatric emergency department with complaints of unease for 3 days and having a seizure half an hour ago. The patient with no remarkable family history had mental-motor retardation due to hypoxic-ischemic encephalopathy and history of being treated with valproic acid for 4 years with diagnosis of epilepsy. His general condition was moderate, he was in the postictal phase with a $\mathrm{SpO}_{2}$ of $93-95 \%$, body temperature of $36.7^{\circ} \mathrm{C}$, heart rate of $102 / \mathrm{min}$, blood pressure of $102 / 67 \mathrm{mmHg}$ and respiration rate of $24 / \mathrm{min}$. On physical examination, he had penile erection with relatively glans penis (Figure 1). During taking the history, it was learned that this condition was present for three days and he had no history of trauma. Examination of the other systems was normal. Laboratory work-ups requested for etiology of priapism were found to be normal. The patient was consulted with department of urology, a corporeal aspiration was performed and a blood gas analysis was requested, which was consistent with ischemic priapism $\left(\mathrm{PO}_{2}: 25 \mathrm{mmHg}, \mathrm{PCO}_{2}: 82 \mathrm{mmHg}\right.$, $\mathrm{pH}: 7.21)$. Low rate of blood flow within cavernous arteries were also consistent with ischemic priapism. A cavernous aspiration was performed; however, because of failure to achieve detumescence and a history of priapism that had lasted longer than three days, treatment with a surgical shunt was considered. However, his parents refused due to mental-motor retardation of the patient. Treatment with terbutalin at a dose of $0.05 \mathrm{mg} / \mathrm{kg} /$ dose every 8 hours was initiated. The patient was considered to have valproic acidinduced priapism and the medication discontinued. Patient's complaint of priapism improved three days after discontinuation of the medication.



Figure 1. A case of valproic acid-induced priapism

\section{Discussion}

Priapism has three distinct types: Ischemic (venoocclusive, low-flow), non-ischemic (arterial, highflow) and stuttering (intermittent, recurrent ischemic). Ischemic priapism is the type which is usually painful and the most common in children. Its etiology includes hematologic disorders, history of medication use (a-Adrenergic receptor antagonists, anticoagulants, antidepressants, antipsychotics, antihypertensive drugs, hormones, vasoactive drugs), malignancies and neurological disorders. ${ }^{3,4}$ Main objective of the treatment is rapid restoration of cavernous blood flow in order to prevent end organ damage and erectile dysfunction. Hypoxia and acidosis lead to cavernous fibrosis within four hours and focal necrosis within 24 hours and diffuse necrosis within 48 hours. ${ }^{5}$ Non-ischemic priapism is a rare condition that occurs in case of an irregular high arterial blood flow to the corpora cavernosa due to rupture of cavernous artery secondary to a penile, perineal or pelvic trauma. Painful, recurrent, self-limiting long-lasting erections that may precede ischemic priapism is called stuttering (recurrent) priapism. ${ }^{6,7}$ History, physical examination and blood taken from the corpora cavernosa can differentiate ischemic from non-ischemic priapism. Blood taken from the ischemic priapism has a $\mathrm{pH}<7.25, \mathrm{pO}_{2}<30 \mathrm{mmHg}$ and is darkcolored, whereas in the non-ischemic variant, it has a $\mathrm{pH}>7.30, \mathrm{pO}_{2}>50 \mathrm{mmHg}$ and is bright red. A color Doppler of penis and perineum is the gold standard for access to blood flow to the corpora cavernosa and differentiates the ischemia from normal-high-flow nonischemic priapism. ${ }^{8}$

The basis for mechanism of action of drug-induced priapism is development of hypoxia and ischemia due to irregular tonus of smooth muscles localized in penile vascular tissues. ${ }^{9}$ In the literature, an adult case of valproic acid-induced priapism, similar to ours, was published by Bansal et al. ${ }^{10}$ Our case is the first pediatric case report of valproic acid-induced priapism.

\section{Conclusion}

Priapism is a urologic emergency that varies by ischemic and non-ischemic episodes. Ischemic injury to cavernous tissues leads to erectile dysfunction. Early recognition of priapism, determination of the type and the treatment are crucial in preventing potential long-term complications caused by priapism.

Author Contributions: Concept: E.T, A.Y, F.A, A.O.K; Design: E.T., A.Y; Analysis or Interpretation: E.T, A.Y, F.A; Literature Search: E.T, A.Y, A.O.K; Writing: E.T, A.Y.

Conflict of Interest: There are no conflicts of interest in connection with this paper, and the material described is not under publication or consideration for publication elsewhere.

Financial Disclosure: The authors declared that this study has received no financial support

Informed Consent: Written informed consent was obtained from patients who participated in this study.

Peer-review: Externally peer-reviewed.

\section{References}

1. Hirshberg SJ, Charles RS, Ettinger JB. Pediatric priapism associated with Mycoplasma pneumoniae. Urology. 1996;47:745746. [CrossRef]

2. Donaldson JF, Rees RW, Steinbrecher HA. Priapism in children: a comprehensive review and clinical guideline. J Pediatr Urol. 2014;10:11-24. [CrossRef]

3. Broderick GA, Kadioglu A, Bivalacqua TJ, et al. Priapism: pathogenesis, epidemiology, and management. J Sex Med. 2010;7:476-500. [CrossRef]

4. Hwang T, Shah T, Sadeghi-Nejad H. A Review of Antipsychotics and Priapism. Sex Med Rev. 2020;S2050-0521(20)30112-8. [CrossRef] 
5. Kadioglu A, Sanli O, Celtik M, et al. Practical management of patients with priapism. EAU-EBU update series. 2006;4:150-160. [CrossRef]

6. Huang YC, Harraz AM, Shindel AW, et al. Evaluation and management of priapism: 2009 update. Nat Rev Urol. 2009;6:262271. [CrossRef]

7. Liguori G, Rizzo M, Boschian R, et al. The management of stuttering priapism. Minerva Urol Nefrol. 2020;72:173-186. [CrossRef]
8. Corbetta JP, Durán V, Burek $\mathrm{C}$, et al. High flow priapism: diagnosis and treatment in pediatric population. Pediatr Surg Int. 2011;27:1217-1221. [CrossRef]

9. Yuan J, Desouza R, Westney OL, et al. Insights of priapism mechanism and rationale treatment for recurrent priapism. Asian J Androl. 2008;10:88-101. [CrossRef]

10. Bansal S, Gupta SK. Sodium valproate induced priapism in an adult with bipolar affective disorder. Indian J Pharmacol. 2013;45:629-630. [CrossRef] 